\title{
Tokat İli Kent Merkezindeki Yaş Sebze Meyve Tedarik Noktasının Seçiminde Etkili Olan Faktörler
}

\section{Berrin DAL ${ }^{1}$ (D) Halil KIZILASLAN2}

${ }^{1}$ Gaziosmanpaşa Üniversitesi, Almus Meslek Yüksekokulu, ${ }^{2}$ Gaziosmanpaşa Üniversitesi, Ziraat Fakültesi, Tarım Ekonomisi Bölümü, Tokat $\bowtie$ : berrin.dal@gop.edu.tr

\begin{abstract}
ÖZET
$\mathrm{Bu}$ çalışmanın amacı, tüketicilerin yaş sebze meyve tedarik kanalı seçimi ve bunları seçmelerinde etkili olan faktörlerin ortaya konulmasıdır. Çalışma kapsamında Tokat ili kentsel alanındaki hane halkı ile yüz yüze görüşmelerden elde edilen veriler kullanılmıştır. Çalışmada, tüketicilerin yaş sebze meyve tedarikinde süpermarket, market, manav, semt pazarı alternatiflerinden hangisini tercih ettikleri ve bu seçimde etkili olan kriterlerin (uygun fiyat, taze ürün, kaliteli ürün, çeşitli ürün, kolay ulaşım, istenilen miktarda alabilme, toplu alışveriş, park olanakları, organik ürün, ürünü seçerek alma, alışkanlık, servis imkanı, her mevsimde bulabilme, temizlik) tüketici tercihindeki önemlilik derecesi Analitik Hiyerarşik Süreç yöntemi ile belirlenmiştir. Elde edilen bulgular doğrultusunda tüketicilerin en çok temizliğe $(0,125)$ dikkat ettiği, ikinci olarak ise ürünü seçerek almaya $(0,093)$ önem verdiği belirlenmiştir. Yaş sebze meyve tedarikinde ise süpermarketin $\% 40^{\prime}$ lık değer ile ilk sirada, semt pazarının ise \%22 ile ikinci sırada yer aldığı gözlemlenmiştir.
\end{abstract}

Makale Tarihçesi

Geliş : 18.10 .2018

Kabul : 27.12.2018

Anahtar Kelimeler

Yaş Sebze Meyve,

Tedarik Noktası,

Analitik Hiyerarşik Süreç,

Tokat

Araştırma Makalesi

\section{Factors Affecting the Selection of Fresh Vegetable and Fruit Supply Point in the City Center of Tokat Province}

\begin{abstract}
The aim of this study was to see the consumers selection of vegetable fruit supply channels and to determine the factors that are effective in the selection. The data that used within the scope of the study was obtained from face-to-face interviews with households in the urban area of Tokat province. In this study, which of the alternatives of supermarket, markets, greengrocer, neighborhood market in the supply of fresh vegetable fruit is preferred by consumers and the criteria (affordable price, fresh products, quality products, various products, easy transportation, shopping, park facilities, organic product, product selection, habit, service facility, hygiene, all seasons to find that are effective in this selection, was determined by the analytical hierarchical process method. According to the findings, it was determined that the consumers paid the most attention to cleanliness (0.125) and secondly, they consider picking the product as important (0.093). In the supply of fresh fruits and vegetables, the supermarket was ranked first with $40 \%$ and the neighborhood market with $22 \%$.
\end{abstract}

\section{Article History}

Received : 18.10 .2018

Accepted : 27.12.2018

Keywords
Fresh Vegetable Fruit,
Supply Point,
Analytical Hierarchical Process,
Tokat.

Research Article

To cite: Dal B, Kızılaslan H 2018. Tokat İli Kent Merkezindeki Yaş Sebze Meyve Tedarik Noktasının Seçiminde Etkili Olan Faktörler. KSÜ Tar Doğa Derg 21(Özel Sayı) : 80-85, DOI : 10.18016/ ksutarimdoga.vi.472165

\section{GíRİ̧̧}

Beslemenin vazgeçilmezi olan yaş sebze meyve ülke ekonomisinde de önemli bir yere sahiptir. Değişen yaşam koşulları tüketici taleplerinin çoğalmasına ve de çeşitlenmesine neden olmuştur. Ürünün çeşitliliği, kalitesi, hijyen, alışveriş yapılan yerin birden fazla ihtiyaca cevap vermesi, istenilen miktarda ürün alabilme, otopark ihtiyacı, toplu alışveriş ve daha birçok konuda tüketici talepleri ortaya çıkmıştır. $\mathrm{Bu}$ durum perakendeciler için yol gösterici olmasının ve rekabeti artırmasının yanı sıra pazarlama açısından da değişiklikleri ve yenilikleri beraberinde getirmiştir. 
Perakendecileri tüketici tercihlerini etkileyebilmek için pazarlama karmasını sürekli olarak geliştirmelerine ve yeni stratejiler uygulamaları için yönlendirmektedir. Perakendeciler, mal ve hizmet çeşitliliğine ve hizmet sunumuna dayalı ürün farklılaştırması, fiyat farklılaştırmasına dayalı fiyatlandırma stratejileri ve çeşitli satış geliştirme çabalarını pazarlama stratejileri ile destekleyerek birbirleri ile rekabet etmektedirler. Bu yönü ile perakendecilik sektörü son derece dinamik bir yapı arz etmekte ve perakendecilik sektöründe hızlı değişimler yaşanmaktadır (Polat ve Külter, 2007:2; Doğan ve ark., 2014).

Türkiye' de yaş meyve sebze pazarlama zincirinde yer alan perakende satış noktaları 1990' lı yıllara kadar semt pazarları, manavlar ve seyyar satıcılardan oluşmakta iken bu halkaya 1990' lı yıllarda modern perakendeciler olarak tanımlanan organize ve kurumsallaşmış bir yapı sergileyen yerel, ulusal ve uluslararası süper ve hipermarket zincirleri de dahil olmuştur (Akpınar ve ark., 2009).

$\mathrm{Bu}$ çalışmada Tokat ilindeki tüketicilerin yaş sebze meyve tedarikinde hangi kanall tercih ettikleri ve bunun tercihinde etkili olan etmenler araştırılmıştır. Elde edilen bulgular sonucunda, tüketici tercihleri belirlenerek, yaş sebze meyve tedarikinde yer alan sektörlerin yeni stratejiler geliştirmeleri için yol gösterici olması ve tüketici ihtiyaçlarına maksimum düzeyde cevap verebilmesi amaçlanmıştır.

\section{MATERYAL ve YÖNTEM}

\section{Verilerin Toplanması Aşamasında İzlenen Yöntem}

Araştırmanın verileri Tokat il merkezinde bulunan tüketicilerden anket yoluyla elde edilmiştir. Anket uygulamasında örneklem hacmi belirlemede kullanılan yöntemlerden Ana Kütle Oranlarına Dayalı Kümelendirilmemiş Tek Aşamalı Basit Tesadüfî Olasılık Örneklemesi yöntemiyle belirlenmiştir (Collins, 1986; Akbay ve ark., 2007 ). Buna göre araştırmada kullanılan örnekleme formülü aşağıda tanımlanmıştır (Collins, 1986):

$\mathrm{n}=\mathrm{t}^{2}(\mathrm{p} * \mathrm{q}) / \mathrm{e}^{2}$

Burada;

t: \%90 önem düzeyine karşıllk gelen t-tablo değerini $(1,65)$

p: İncelenen olayın ana kütle içinde gerçekleşme olasılığ (\%50)

q: İncelenen olayın gerçekleşmeme olasılığ $(1-p)$

e: Örneklemede kabul edilen hata oranını vermektedir (\%5)

Çalışmada, incelenen olayın ana kütle içinde gerçekleşme olasılığı örnek hacmini maksimum kılacak şekilde \%50 olarak alınmış, \%90 önem düzeyinde ve $\% 5$ hata payı ile kabul edilerek örnek hacmi 272 olarak bulunmuştur.

\section{Verilerin Analizi Aşamasında İzlenen Yöntem}

Verilerin analizinde "SPSS V.23" programindan yararlanılmıştır. Tüketicilerin yaş sebze meyve satın alma noktaları ve bunu etkileyen faktörlerin belirlenmesinde ise Analitik Hiyerarşik Süreç (AHS) yöntemi kullanılmıştır. AHS' nin ilk aşaması, karar problemini temel bileşenlerine ayrıştırmak ve hiyerarşik bir yapı oluşturmaktır. Karar amacı ile tepeden başlayarak karar hiyerarşisi oluşturulur. Orta seviyede kriterler, en düşük seviyede ise alternatifler bulunur (Saaty, 2008). Şekil 1' de hiyerarşik yapı örneği verilmiştir.

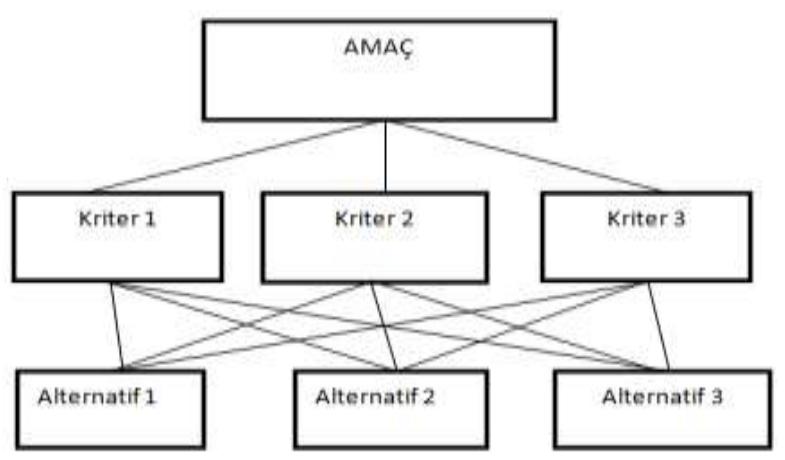

Şekil 1. Bir hiyerarşik yapı

İkinci aşamasını ise ikili karşılaştırmalardır. İkili karşılaştırma yapılırken Thomas L. Saaty tarafindan önerilen Çizelge 1' de verilen 1-9 temel ölçeğinden yararlanılır. Ağırlıkların birleştirilerek sonuca ulaşılması ve tutarlılık oranının hesaplanması ise son aşamada gerçekleşmektedir. Eğer tutarlılık oranı, 0.10 'dan daha büyük bir değer çıkarsa, bu ikili karşılaştırmaların doğru olarak yapılamadığı anlamına gelir ve karşılaştırma matrisinin tekrar düzenlenmesini gerektirir (Satty, 1994). Elde edilen ikili karşılaştırma matrisleri, geometrik ortalama yaklaşımı ile birleştirilerek grup karşılaştırma karar matrisleri oluşturulmuştur. Elde edilen karar matrisleri Super Decisions programına aktarılmıştır. Öncelikle kriterler, daha sonrada her bir kriter için alternatifler karşılaştırılmıştır.

\section{ARAŞTIRMA BULGULARI}

Tokat ilindeki tüketicilerin sosyo-demografik özellikleri Çizelge $2^{\prime}$ de verilmiştir. Tüketicilerin \%39,3' ünün 36-50 yaş aralığinda olduğu ve \% 51,8' inin kadın tüketicilerden oluştuğu görülmektedir. Tüketicilerin \% 49,6' sinın üniversite mezunu, \% 40,4' ünün memur, \% 13,2' si ise işsizdir. Tüketicilerin $\%$ 63,6 ' sı evli ve \% 67,8' inin eşleri herhangi bir işte çalışmaktadır. Ayrıca eşlerin eğitim durumu incelendiğinde $\% 48,3$ ünün üniversite mezunu olduğu ve $\% 42,5$ oranında memur olarak çalıştığ belirlenmiştir. Tüketicilerin ailedeki birey sayıları incelendiğinde \%47,4'ünün 4-6, \%47,1'inin ise 1-3 kişilik olduğu ortaya konulmuştur. 
Çizelge 1. AHS' de kullanılan 1-9 temel ölçeği

\begin{tabular}{|c|l|l|}
\hline Önem Derecesi & \multicolumn{1}{|c|}{ Tanım } & \multicolumn{1}{c|}{ Açıklama } \\
\hline 1 & Eşit önemli & İki aktivite de amaca eşit olarak katkıda bulunmaktadır. \\
\hline 3 & Zayıf derecede önem & $\begin{array}{l}\text { Tecrübe ve yargı çok az bir şekilde bir aktiviteyi diğerine karşı } \\
\text { daha çok favori tutar. }\end{array}$ \\
\hline 5 & Güçlü önem & $\begin{array}{l}\text { Tecrübe ve yargı güçlü bir şekilde bir aktiviteyi diğerine karşı } \\
\text { daha çok favori tutar. }\end{array}$ \\
\hline 7 & $\begin{array}{l}\text { Çok güçlü veya } \\
\text { kanıtlanmış önem }\end{array}$ & $\begin{array}{l}\text { Bir aktivite diğerine karşı çok güçlü bir şekilde tercih edilir ve } \\
\text { üstünlüğü pratikte örneklerle kantlanmıstır. }\end{array}$ \\
\hline 9 & Kesin önem & $\begin{array}{l}\text { Bir aktiviteyi diğerine göre seçmenin en yüksek şekilde olduğu } \\
\text { durumdur ve bu üstünlüğü gösteren kanıt çok büyük bir } \\
\text { güvenilirliğg sahiptir. }\end{array}$ \\
\hline $2,4,6,8$ & $\begin{array}{l}\text { Cook yakın skala } \\
\text { değerleri arasındaki ara } \\
\text { değerler }\end{array}$ & $\begin{array}{l}\text { Uzlaşma gerektiğinde kullanılmak üzere iki ardışı yargı } \\
\text { arasındaki değerlerdir. Tercih değerleri birbirine çok yakın ise } \\
\text { kullanılır. }\end{array}$ \\
\hline
\end{tabular}

Kaynak: Saaty, 1990.

Çizelge 2. Tüketicilerin sosyo-demografik özellikleri

\begin{tabular}{|c|c|c|c|c|c|c|c|}
\hline \multicolumn{2}{|c|}{ Sosyo Demografik Özellikler } & Frekans & Yüzde & \multicolumn{2}{|c|}{ Sosyo Demografik Özellikler } & Frekans & Yüzde \\
\hline \multirow{5}{*}{ Yaş } & $18-25$ & 62 & 22,8 & \multirow{7}{*}{$\begin{array}{l}\text { Eşin Eğitim } \\
\text { Durumu }\end{array}$} & Okur yazar/ve altı & 7 & 4.0 \\
\hline & $26-35$ & 64 & 23,5 & & İlkokul mezunu & 26 & 14.9 \\
\hline & $36-50$ & 107 & 39,3 & & Ortaokul mezunu & 11 & 6.3 \\
\hline & $51^{-+}$ & 39 & 14,3 & & Lise mezunu & 28 & 16.1 \\
\hline & Toplam & 272 & 100 & & Yüksekokul & 18 & 10.3 \\
\hline \multirow{3}{*}{ Cinsiyeti } & Kadın & 141 & 51,8 & & Üniversite & 84 & 48.3 \\
\hline & Erkek & 131 & 48,2 & & Toplam & 174 & 100 \\
\hline & Toplam & 272 & 100 & \multirow{8}{*}{ Eşin Mesleği } & Ev hanımı & 45 & 25.9 \\
\hline \multirow{7}{*}{$\begin{array}{l}\text { Eğitim } \\
\text { Durumu }\end{array}$} & Okur yazar/ve altı & 7 & 2,6 & & İş̧̧i & 16 & 9.2 \\
\hline & İlkokul mezunu & 21 & 7,7 & & Memur & 74 & 42.5 \\
\hline & Ortaokul mezunu & 8 & 2,9 & & Serbest Meslek & 25 & 14.4 \\
\hline & Lise mezunu & 56 & 20,6 & & Emekli & 11 & 6.3 \\
\hline & Yüksekokul & 45 & 16,5 & & İşsiz & 2 & 1.1 \\
\hline & Üniversite & 135 & 49,6 & & Çiftçi & 1 & 0.6 \\
\hline & Toplam & 272 & 100 & & Toplam & 174 & 100 \\
\hline \multirow{8}{*}{ Mesleği } & Ev hanımı & 38 & 14,0 & & $1-3$ & 128 & 47.1 \\
\hline & İş̧̧i & 22 & 8,1 & Ailedeki & $4-6$ & 129 & 47.4 \\
\hline & Memur & 110 & 40,4 & Birey Sayısı & 7-+ & 15 & 5.5 \\
\hline & Serbest Meslek & 48 & 17,6 & & Toplam & 272 & 100 \\
\hline & Emekli & 12 & 4,4 & \multirow{6}{*}{ Aylık Gelir } & $0-1000$ & 9 & 3.3 \\
\hline & $\dot{I}_{\text {I̧siz }}$ & 36 & 13,2 & & $1001-1500$ & 13 & 4.8 \\
\hline & Çiftçi & 6 & 2,2 & & $1501-2000$ & 44 & 16.2 \\
\hline & Toplam & 272 & 100 & & $2001-2500$ & 45 & 16.5 \\
\hline \multirow{4}{*}{$\begin{array}{l}\text { Medeni } \\
\text { Hali }\end{array}$} & Bekar & 86 & 31,6 & & $2500^{-+}$ & 161 & 59.2 \\
\hline & Evli & 173 & 63,6 & & Toplam & 272 & 100 \\
\hline & Boşanmış & 13 & 4,8 & \multirow{3}{*}{$\begin{array}{l}\text { Otomobil } \\
\text { Sahipliği }\end{array}$} & Evet & 191 & 70.2 \\
\hline & Toplam & 272 & 100 & & Hayır & 81 & 29.8 \\
\hline \multirow{3}{*}{$\begin{array}{l}\text { Eşin } \\
\text { Çalışma } \\
\text { Durunu }\end{array}$} & Evet & 118 & 67,8 & & Toplam & 272 & 100 \\
\hline & Hayır & 56 & 32,2 & & & & \\
\hline & Toplam & 174 & 100 & & & & \\
\hline
\end{tabular}

Tüketicilerin \%59,2'sinin 2500 TL ve üzeri, $\% 16,5$ 'inin 2001-2500 TL arası, \%16,2'sinin ise 1501-2000TL arası gelire sahip oldukları görülmüştür. Tüketicilerin $\% 70,2^{\prime}$ sinin otomobil sahibi olduğu, \%29,82' inin ise otomobilinin olmadığı belirlenmiştir. Çalışmanın ikinci kısmında ise AHS yöntemi kullanılarak, tüketicilerin yaş sebze meyve tedarikinde etkili olan etmenleri belirlemek için öncelikle hiyerarşik yapı oluşturulmuştur. Hiyerarşik yapıyı oluştururken ise kriterler ve alternatifler belirlenmiştir. Tüketicilerin 
yaş sebze meyve tedarik kanalı seçiminde etkili olan kriterler uygun fiyat (K1), taze ürün (K2), kaliteli ürün (K3), çeşitli ürün (K4), kolay ulaşım (K5), istenilen miktarda alabilme (K6), toplu alışveriş (K7), park olanakları (K8), organik ürün (K9), ürünü seçerek alma (K10), alışkanlık (K11), servis imkanı (K12), her mevsimde bulabilme (K13) ve hijyen (K14) olarak belirlenirken, tedarik kanalları ise süpermarket, market, manav ve semt pazarı olarak belirlenmiştir. Hiyerarşik ağaç modeli Şekil 2' de verilmiştir.

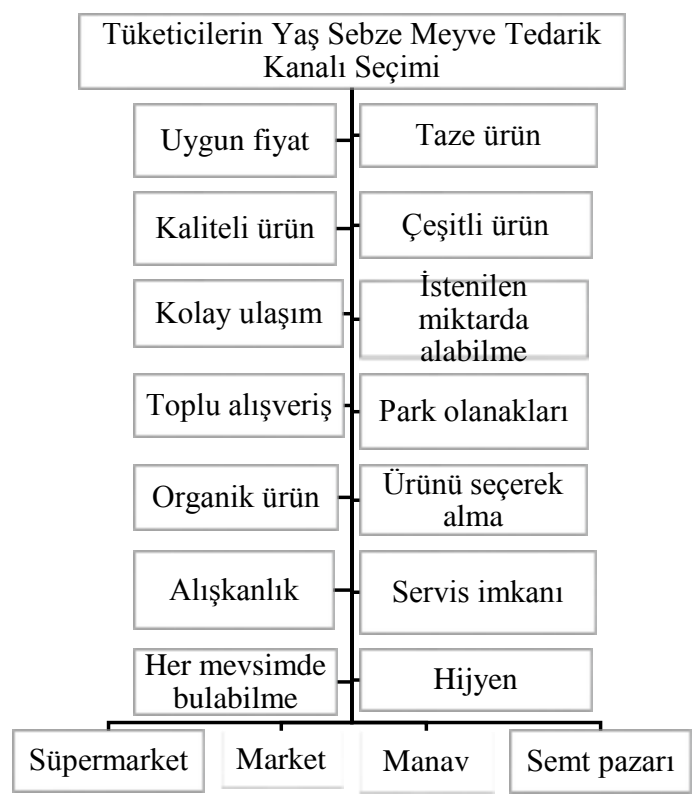

Şekil 2. Hiyerarşik ağaç modeli

Kriterlerin karşılaştırma matrisi ve göreli önem değerleri Çizelge 3’te görülmektedir. Buna göre en önemli kriter 0,125 değeri ile hijyen kriteri olarak belirlenmiştir. Bunu takiben 0,093 ile ürünü seçerek alma, 0.079 ile organik ürün, 0,077 ile kaliteli ürün kriterleri gelmektedir. Antalya' da yapılan benzer bir çalışmada faktörlerin ağırlıklarına bakıldığında, temizlik-hijyen $(0,524)$, ürünü seçerek alma $(0,292)$, alışkanlık $(0,643)$, organik ürün bulunurluğu $(0,711)$, ürünün kalitesi $(0,604)$ olduğu görülmektedir (Akpınar ve ark., 2009). İstanbul' da yapılan bir çalışmada ise, perakendeciler açısından taze meyve sebzelere yönelik tüketici talepleri sorgulanmıs, perakendecilerin tüketicilerin taleplerini değerlendirmeleri istenmiştir. Buna göre; tazelik (\%25), uygun fiyat (\%25), çeşitlilik $(\% 20,7)$, kaliteli olması $(\% 16,7)$, her mevsim bulunabilirlik $(\% 4,2)$, temizlik ve hijyen $(\% 4,2)$ ile gida emniyetine uygunluk $(\% 4,2)$ konularının önemli olduğu belirlenmiştir (Pezikoğlu ve ark., 2004). Edirne İli Keşan İlçesi' nde yapılan benzer bir çalışmada, marketten alışveriş yapan tüketicilerin nedenlerine bakıldığında, kaliteli olması $(\% 24,4)$, kart ile ödeme imkanı (\% 32,3), ürün görünüşü (\%25.5), alışkanlık (\%24,3), her şeyi bir arada bulabilme (\%32.7), istenilen gramajın sağlanması $(\% 32,7)$, alışveriş yapılan yerin park olanakları $(\% 29,3)$, organik ürün temini $(\% 30,4)$ ve alışveriş yapılan yerin temiz olması $(\% 26,3)$ kriterlerinin etkili olduğu görülmektedir. Alışverişlerini manavdan yapan tüketicilerin nedenlerine bakıldığında ise, ürün çeşitliliğinin olması $(\% 33,3)$ ve istenilen gramajın sağlanması $(\% 33,4)$ kriterleri etkili olurken; Yerel pazarlardan meyvesebze alışverişlerini yapan tüketicilerde ise, ucuz olması $(\% 37,5)$, taze olması $(\% 35,0)$, ürün çeşitliliğinin olması $(\% 37,80)$, fiyatın uygun olması $(\% 36,2)$, eve yakın olması $(\% 40,8)$, alışkanlık $(\% 36,2)$ kriterlerinin etkili olduğu tespit edilmiştir (Doğan ve ark., 2014).

Matrislerde tutarlılık oranı 0,10' un altında çıkmıştır. $\mathrm{Bu}$ durumda matrisler tutarlıdır. Tutarlılık oranının 0.10' dan büyük çıkması durumunda karar vericinin kriterlerini yeniden gözden geçirmesi gerekmektedir. Kriterlerin karşılaştırması yapıldıktan sonra her bir kritere göre alternatiflerin karşılaştırması yapılmıştır. Her bir kriterine göre alternatiflerin karşılaştırılması matrisi ve göreli önem değerleri Çizelge 4'te verilmişstir.

Çizelge 3. Kriterlerin karşılaştırılması matrisi

\begin{tabular}{|l|c|c|c|c|c|c|c|c|c|c|c|c|c|c|c|}
\hline & K1 & K2 & K3 & K4 & K5 & K6 & K7 & K8 & K9 & K10 & K11 & K12 & K13 & K14 & Ağırlklar \\
\hline K1 & 1 & 0.61 & 0.60 & 0.85 & 0.74 & 0.86 & 0.83 & 0.80 & 0.72 & 0.51 & 0.81 & 1.04 & 0.92 & 0.43 & 0.052 \\
\hline K2 & 1.63 & 1 & 0.70 & 0.81 & 0.82 & 0.97 & 1.02 & 1.17 & 0.96 & 0.76 & 1.03 & 1.29 & 1.28 & 0.83 & 0.070 \\
\hline K4 & 1.67 & 1.43 & 1 & 1.17 & 0.97 & 1.05 & 1.16 & 1.24 & 0.89 & 0.85 & 1.10 & 1.34 & 1.39 & 0.68 & 0.077 \\
\hline K5 & 1.35 & 1.22 & 1.03 & 1 & 0.84 & 0.84 & 0.82 & 1.11 & 0.77 & 0.60 & 0.89 & 1.12 & 1.06 & 0.54 & 0.062 \\
\hline K6 & 1.17 & 1.02 & 0.95 & 1.20 & 1 & 0.90 & 0.96 & 1.05 & 0.77 & 0.63 & 0.86 & 1.01 & 0.94 & 0.49 & 0.065 \\
\hline K7 & 1.21 & 0.98 & 0.86 & 1.22 & 1.04 & 1.25 & 0.80 & 0.81 & 0.65 & 0.58 & 0.78 & 0.90 & 0.80 & 0.46 & 0.059 \\
\hline K8 & 1.25 & 0.86 & 0.81 & 0.90 & 0.95 & 1.24 & 1.34 & 1 & 0.70 & 0.65 & 0.81 & 0.96 & 0.74 & 0.48 & 0.061 \\
\hline K9 & 1.39 & 1.04 & 1.12 & 1.30 & 1.29 & 1.55 & 1.59 & 1.43 & 1 & 0.72 & 1.01 & 1.16 & 1.15 & 0.68 & 0.079 \\
\hline K10 & 1.98 & 1.32 & 1.17 & 1.68 & 1.59 & 1.72 & 1.75 & 1.55 & 1.39 & 1 & 1.12 & 1.35 & 1.14 & 0.68 & 0.093 \\
\hline K11 & 1.32 & 0.98 & 0.91 & 1.12 & 1.17 & 1.27 & 1.34 & 1.24 & 0.99 & 0.89 & 1 & 0.99 & 1.03 & 0.54 & 0.071 \\
\hline K12 & 0.96 & 0.77 & 0.75 & 0.88 & 0.99 & 1.11 & 1.01 & 1.04 & 0.86 & 0.74 & 1.01 & 1 & 0.79 & 0.47 & 0.060 \\
\hline K13 & 1.09 & 0.78 & 0.72 & 0.94 & 1.06 & 1.25 & 1.20 & 1.35 & 0.87 & 0.87 & 0.97 & 1.26 & 1 & 0.36 & 0.066 \\
\hline K14 & 2.35 & 1.21 & 1.48 & 1.85 & 2.02 & 2.19 & 2.01 & 2.07 & 1.47 & 1.47 & 1.87 & 2.11 & 2.76 & 1 & 0.125 \\
\hline
\end{tabular}

Tutarlılık Oranı: 0,006 
Çizelge 4. Kriterlere göre alternatiflerin karşılaş̧tırılması matrisi

\begin{tabular}{|c|c|c|c|c|c|c|}
\hline & & Süpermarket & Market & Manav & Semt pazarı & Ağırlıklar \\
\hline \multirow{4}{*}{$\begin{array}{c}\text { Uygun Fiyat } \\
\text { (Tutarlılık Oranı:0,011) }\end{array}$} & Süpermarket & 1 & 2,23 & 1,64 & 0,85 & 0,320 \\
\hline & Market & 0,45 & 1 & 1,14 & 0,61 & 0,180 \\
\hline & Manav & 0,60 & 0,87 & 1 & 0,64 & 0,181 \\
\hline & Semt pazarı & 1,18 & 1,63 & 1,57 & 1 & 0,319 \\
\hline \multirow{2}{*}{ Taze Ürün } & Süpermarket & 1 & 2,51 & 1,02 & 0,70 & 0,277 \\
\hline & Market & 0,40 & 1 & 0,73 & 0,53 & 0,149 \\
\hline \multirow{2}{*}{ (Tutarlılık Oranı:0,023) } & Manav & 0,98 & 1,37 & 1 & 0,60 & 0,214 \\
\hline & Semt pazarı & 1,42 & 1,88 & 1,66 & 1 & 0,360 \\
\hline \multirow{4}{*}{$\begin{array}{c}\text { Kaliteli Ürün } \\
\text { (Tutarlılık Oranı: 0,015) }\end{array}$} & Süpermarket & 1 & 2,76 & 1,71 & 1,31 & 0,380 \\
\hline & Market & 0,36 & 1 & 0,99 & 0,90 & 0,181 \\
\hline & Manav & 0,58 & 1,01 & 1 & 0,82 & 0,198 \\
\hline & Semt pazarı & 0,76 & 1,10 & 1,22 & 1 & 0,241 \\
\hline \multirow{2}{*}{ Çeşitli Ürün } & Süpermarket & 1 & 3,23 & 2,15 & 1,27 & 0,404 \\
\hline & Market & 0,30 & 1 & 1,14 & 0,74 & 0,167 \\
\hline \multirow{2}{*}{ (Tutarlılık Oranı:0,016) } & Manav & 0,46 & 0,88 & 1 & 0,66 & 0,167 \\
\hline & Semt pazarı & 0,79 & 1,36 & 1,51 & 1 & 0,262 \\
\hline \multirow{2}{*}{ Kolay Ulaşım } & Süpermarket & 1 & 1,96 & 1,57 & 1,48 & 0,357 \\
\hline & Market & 0,51 & 1 & 1,41 & 1,29 & 0,239 \\
\hline \multirow{2}{*}{ (Tutarlılık Oranı:0,016) } & Manav & 0,64 & 0,71 & 1 & 1,15 & 0,205 \\
\hline & Semt pazar1 & 0,68 & 0,78 & 0,87 & 1 & 0,199 \\
\hline \multirow{3}{*}{$\begin{array}{l}\text { İstenilen Miktarda } \\
\text { Alabilme }\end{array}$} & Süpermarket & 1 & 2,17 & 1,56 & 1,17 & 0,345 \\
\hline & Market & 0,46 & 1 & 1,09 & 0,94 & 0,203 \\
\hline & Manav & 0,64 & 0,92 & 1 & 0,79 & 0,200 \\
\hline (Tutarlılık Oranı:0,011) & Semt pazarı & 0,85 & 1,06 & 1,26 & 1 & 0,252 \\
\hline \multirow{4}{*}{$\begin{array}{c}\text { Toplu Alışveriş } \\
\text { (Tutarlılık Oranı:0,033) }\end{array}$} & Süpermarket & 1 & 3,30 & 2,37 & 1,89 & 0,453 \\
\hline & Market & 0,30 & 1 & 1,70 & 1,30 & 0,207 \\
\hline & Manav & 0,42 & 0,58 & 1 & 0,85 & 0,153 \\
\hline & Semt pazarı & 0,53 & 0,76 & 1,17 & 1 & 0,187 \\
\hline \multirow{4}{*}{$\begin{array}{c}\text { Park Olanakları } \\
\text { (Tutarlılık Oranı:0,040) }\end{array}$} & Süpermarket & 1 & 2,83 & 2,60 & 2,44 & 0,462 \\
\hline & Market & 0,35 & 1 & 1,90 & 2,07 & 0,241 \\
\hline & Manav & 0,39 & 0,53 & 1 & 1,59 & 0,165 \\
\hline & Semt pazarı & 0,41 & 0,48 & 0,63 & 1 & 0,132 \\
\hline \multirow{2}{*}{ Organik Ürün } & Süpermarket & 1 & 2,42 & 1,17 & 0,82 & 0,296 \\
\hline & Market & 0,41 & 1 & 0,72 & 0,57 & 0,154 \\
\hline \multirow{2}{*}{ (Tutarlılık Oranı:0,013) } & Manav & 0,86 & 1,38 & 1 & 0,57 & 0,217 \\
\hline & Semt pazarı & 1,22 & 1,75 & 1,75 & 1 & 0,333 \\
\hline \multirow{4}{*}{$\begin{array}{l}\text { Ürünü Seçerek Alma } \\
\text { (Tutarlılık Oranı:0,023) }\end{array}$} & Süpermarket & 1 & 2,93 & 2,21 & 1,51 & 0,418 \\
\hline & Market & 0,34 & 1 & 1,40 & 1,01 & 0,196 \\
\hline & Manav & 0,45 & 0,72 & 1 & 0,93 & 0,172 \\
\hline & Semt pazar1 & 0,66 & 0,99 & 1,08 & 1 & 0,214 \\
\hline \multirow{2}{*}{ Alışkanlık } & Süpermarket & 1 & 2,37 & 1,91 & 1,30 & 0,376 \\
\hline & Market & 0,43 & 1 & 1,46 & 0,95 & 0,210 \\
\hline \multirow{2}{*}{ (Tutarlılık Oranı:0,016) } & Manav & 0,52 & 0,69 & 1 & 0,77 & 0,173 \\
\hline & Semt pazarı & 0,76 & 1,05 & 1,30 & 1 & 0,241 \\
\hline Servic İmkanı & Süpermarket & 1 & 3,62 & 2,93 & 2,96 & 0,510 \\
\hline Dervis IIIIKant & Market & 0,28 & 1 & 2,00 & 1,98 & 0,219 \\
\hline (Tutarlılık Oranı:0,042) & Manav & 0,34 & 0,50 & 1 & 1,37 & 0,146 \\
\hline (1 utarmink Uran1·0,04Z) & Semt pazarı & 0,33 & 0,51 & 0,73 & 1 & 0,125 \\
\hline Her Meysim Bulabilme & Süpermarket & 1 & 3,32 & 2,38 & 2,28 & 0,471 \\
\hline ner vievsim Duradmime & Market & 0,30 & 1 & 1,39 & 1,15 & 0,188 \\
\hline (Tutarllut Orani:0 017) & Manav & 0,42 & 0,72 & 1 & 1,05 & 0,169 \\
\hline 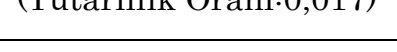 & Semt pazarı & 0,44 & 0,87 & 0,96 & 1 & 0,172 \\
\hline & Süpermarket & 1 & 3,59 & 3,00 & 2,34 & 0,495 \\
\hline Hijyen & Market & 0,28 & 1 & 1,68 & 1,70 & 0,207 \\
\hline (Tutarlyluk Orani:0 041) & Manav & 0,33 & 0,60 & 1 & 1,30 & 0,153 \\
\hline 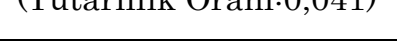 & Semt pazarı & 0,43 & 0,59 & 0,77 & 1 & 0,145 \\
\hline
\end{tabular}


Kriterlere göre alternatiflerin karşılaştırıldığında süpermarketin, uygun fiyat $(0,320)$, kaliteli ürün $(0,380)$, çeşitli ürün $(0,404)$, kolay ulaşım $(0,357)$, istenilen miktarda alabilme $(0,345)$, toplu alışveriş $(0,453)$, park olanakları $(0,462)$, ürünü seçerek alma $(0,418)$, alışkanlık $(0,357)$, servis imkanı $(0,510)$, her mevsim bulabilme $(0,471)$ ve hijyen $(0,495)$ kriterleri açısından öncelikli olduğu ancak taze ürün ve organik ürün kriterleri açısından ikinci sırada yer aldı ğ görülmektedir. Taze ürün $(0,360)$ ve organik ürün $(0,333) \quad$ kriterine göre alternatiflerin karşılaştırıldığında ise semt pazarının ilk sırada yer aldığı görülmektedir.

Kriterlerin ve alternatiflerin ağırlıkları birleştirilerek sonuca ulaşıldığında alternatiflerin göreli önem değerleri elde edilmiştir. Alternatiflerin göreli önem değerleri Çizelge 5'te verilmiştir. Buna göre süpermarket kriteri 0,402 puan ile ilk sirada yer alırken, 0,223 ile semt pazarı kriteri ikinci sırada yer almaktadır. 0,196 puan ile market kriteri üçüncü ve manav kriteri ise 0,179 puan ile dördüncü sırada yer almaktadır. Antalya' da yapılan benzer bir çalışmada, yaş meyve sebze alışverişinde her dört tüketiciden birinin tedarik kanalı tercihinin modern perakendeciler(süper-hipermarket) yönünde olduğu, semt pazarı, manav gibi geleneksel satış noktalarının ise tüketici tercihindeki ağırlığını koruduğu saptanmıştır (Akpınar ve ark., 2009).

Çizelge 5. Alternatiflerin göreli önem değerleri

\begin{tabular}{|l|c|}
\hline & Ağırlıklar \\
\hline Süpermarket & 0,402 \\
\hline Market & 0,196 \\
\hline Manav & 0,179 \\
\hline Semt pazarı & 0,223 \\
\hline
\end{tabular}

\section{SONUÇ ve ÖNERILER}

Değişen yaşam koşulları yenilikleri de beraberinde getirmiştir. Tedarik kanallarının giderek çoğalması tüketicilerin farklı arayışlar içine yönelmesine, yaş sebze meyve tedarikinin yanında farklı ihtiyaçlara da cevap bulabilme arayışı içine girmelerine neden olmuştur. Ürünü seçerek alma, kaliteli ve çeşitli ürün arayışı, hijyen, ulaşım, araç park olanakları, toplu alışveriş yapabilme, organik ürün arayışı istenilen miktarda alabilme bunlardan bazılarıdır. $\mathrm{Bu}$ çalışmada, Tokat ilindeki tüketicilerin yaş sebze ve meyve tedarik kanalı tercihleri ve bunu tercih etmede etkili olan faktörleri incelemek ve sonuçlarını değerlendirmek amaçlanmıştır.

Yaş sebze meyve tedarikinde tüketiciler en çok hijyen $(0,125)$ kriterine dikkat etmektedir. Bunun yanında ürünü seçerek alma $(0,093)$, organik ürün $(0,079)$, kaliteli ürün $(0,077)$ gibi faktörlerde yer almaktadır. Alternatiflerden ise süpermarketler \%40'lık değer ile ilk sırada, semt pazarının ise \%22 ile ikinci sırada yer almaktadır.
Süpermarketler uygun fiyat, kaliteli ürün, çeşitli ürün, kolay ulaşım, istenilen miktarda alabilme, toplu alışveriş, park olanakları, ürünü seçerek alma, alışkanlık, servis imkanı, her mevsimde bulabilme, hijyen kriterlerinde öncelikli olarak belirlenmiştir. Taze ürün, organik ürün kriterlerinde ise ikinci olarak yer almıştır. Bu kriterlerde ise semt pazarları ön plana çıkmıştır. Toplu alışveriş olanakları, servis imkanı, hijyen, ulaşım, park olanaklarında ise marketler ikinci sirada yer almaktadır.

Günümüz koşulları dikkate alındığında tüketicilerin ihtiyaçlarına süpermarketlerin cevap verdiği ve bunu semt pazarlarının izlediği görülmektedir. Ancak süpermarketler taze ürün ve organik ürün açısından zayıf kalmıştır. Süpermarketlerin bu iki kriterde iyileştirilmeleri, tüketici tercihinde etkili olacaktır. Ayrıca taze ürün ve organik ürün açısından en çok tercih edilen semt pazarları birçok noktada ikinci sırada kalmaktadır. Özellikle ulaşım, araç park olanakları, servis imkanı açısından son sıralarda yer aldığı görülmüştür. Semt pazarlarının tüketicilerin kolay ulaşabileceği, araç park sorunu yaşamayacağı alanlara kurulmaları önerilebilir.

\section{KAYNAKLAR}

Akbay C, Tiryaki G, Gül A 2007. Consumer Characteristics Influencing Fast Food Consumption in Turkey, Food Control, 18: 904-913. Akpınar MG, Özkan B, Oral Atalay M, Kızllay H 2009. "Tüketicilerin Yağ Meyve Sebze Tedarik Kanalı Seçimi", Modern (Süper-Hipermarket) Perakendeciler, Akdeniz Üniversitesi Ziraat Fakültesi Dergisi, 22(2): 211-221.

Collins M 1986. Sampling, Consumer Market Research Handbook Country-Of-Origin Labeling, Journal of Agriculture and Applied Economics, 37(1): 49-63.

Doğan HG, Onurlubaş HE, Kızılaslan H 2014. "Edirne İli Keşan İlçesinde Yaşayan Tüketicilerin Meyve Sebze Tüketim Yeri Tercihleri ve Bunu Etkileyen Faktörler" CBÜ Sosyal Bilimler Dergisi, İktisadi ve İdari Bilimler Sayısı. 12(2):13-27

Pezikoğlu F, Ergun ME, Erkal S 2004. Taze MeyveSebze Pazarlama Zincirinde Modern Perakendecilerin Durumu, Bahçe, 33(1-2): 75-84.

Polat C, Külter B 2007. "Tüketicilerin Perakende Mağaza Tercihini Etkileyen Faktörler: Niğde İli Örneği”, Gazi Üniversitesi İktisadi ve İdari Bilimler Fakültesi Dergisi, 9(3):109-126

Saaty TL 1990. Multicriteria Decision Making: The Analytic Hierarchy Process, RWS Publications, 2nd Edition, Pittsburgh, 54.

Saaty TL 1994. "Funamentals of Decision Making and Priority Theory", RWS, Pittsburgh, 95.

Saaty TL 2008. Decision making with the analytic hierarchy process. International Journal of Services Sciences, 1(1): 83-98. 